\title{
PERIDOMESTIC STRUCTURE, FARMING ACTIVITY AND TRIATOMINE INFESTATION
}

\author{
POJO DE REGO I.*, WALTER A.**, FERREIRA A.J.***, RANGEL M.****, GIRARD-FERREIRA E.***** \& NOIREAU F.**
}

\section{Summary:}

The role of peridomestic structure and farming activity on triatomine infestation was studied on two vector species of Chagas disease (Triatoma pseudomaculata and T. brasiliensis) in Bahia State, northeastern Brazil. A randomly selected population issued from 136 farms was divided into four categories according to the householder activity. At regional scale, the dwellings of farmers working on degraded land of irrigated farms are less exposed to T. pseudomaculata infestation. At premises scale, the farmers and casual workers, who have smaller peridomiciles and less cattle, are also less exposed to T. pseudomaculata. The association of $T$. brasiliensis with the most mobile populations (casual workers and young breeders) suggests a passive transport of this competitive species. Finally, the retired farmers that own large premises and cattle, but have more sedentary behavior, are the most exposed to $T$. pseudomaculata infestation.

KEY WORDS : Chagas disease, Triatoma pseudomaculata, Triatoma brasiliensis, dwelling infestation, peridomicile, human behavior, animal husbandry, Brazil.

\section{INTRODUCTION}

T The elimination of Triatoma infestans, the main vector of Chagas disease, was successful over the northeastern Brazil. The control of this imported species has highlighted the synanthropic process of autochthonous Triatominae originally restricted to wild environment or previously occulted by Triatoma infestans invasion. These emergent species invade the peridomestic areas, coming from the surrounding environment. They colonize artificial structures where they maintain the epidemiological cycle of Trypanosoma cruzi close to man. The silvatic triatomines in process of domestication may play an important role in the transmission of Chagas disease. It is the case of Triatoma brasiliensis (Neiva, 1911) (Neiva \& Penna, 1916) and Triatoma pseudomaculata (Corrêa \& Espínola,

\footnotetext{
* Departamento de Sociologia, Universidade de Brasilia, Brazil.

** Institut de Recherche pour le Développement, UR016 (Caractérisation et contrôle des populations de vecteurs)

**** Diretório Regional de Saúde, Brasilia, Brasil.

Correspondence: Annie Walter, IRD, CP 9214, 0095 La Paz, Bolivia.

Fax: 5912782944 - E-mail: annie.walter@ird.fr
}

Résumé : StRUCTURES PÉRIDOMICILIAIRES, ACTIVITÉS AGRO-PASTORALES ET INFESTATION PAR LES TRIATOMES

Le rôle des structures du péridomicile et des activités d'élevage a été étudié à propos de deux vecteurs de la maladie de Chagas (Triatoma pseudomaculata et T. brasiliensis), dans l'état de Bahia, au nord-est du Brésil. La population de 136 fermes, tirées au sort, a été séparée en quatre catégories, en fonction du type d'activité des fermiers. À l'échelle régionale, les demeures des fermiers travaillant sur les terres dégradées des zones d'agriculture irriguée sont moins exposées à l'infestation par T. pseudomaculata. À l'échelle des péridomiciles, les agriculteurs et les journaliers, qui ont de plus petits péridomiciles et moins de bétail, ont aussi des unités d'habitation moins exposées à l'infestation par

T. pseudomaculata. L'association de T. brasiliensis avec la population la plus mobile (journaliers et jeunes éleveurs) suggère un transport passif de cette espèce compétitive. Enfin, les éleveurs retraités, qui ont de vastes péridomiciles et de grands troupeaux, mais un comportement plus sédentaire, sont plus exposés à l'infestation par T. pseudomaculata.

MOTS CLÉS : maladie de Chagas, Triatoma pseudomaculata, Triatoma brasiliensis, infestation, habitat, péridomicile, comportement humain, élevage, Brésil.

1964) that are increasingly reported invading artificial structures (Dias et al., 2002, Costa et al., 2003). Both species are ubiquitous throughout the caatinga ecosystem and are among the three more frequent triatomines captured in man-made structures of this region, mainly in the peridomicile (Silveira \& Vinhaes, 1998; Silveira et al., 1998; Costa et al., 1998; Oliveira-Lima et al., 2000; Sarquis et al., 2004). In natural environment, T. pseudomaculata occurs in hollow tree and bird nest when T. brasiliensis is found in rocky habitat. Their synanthropic process is probably promoted by anthropogenic environmental changes.

From the $17^{\text {th }}$ century, farmers have progressively settled in northeastern Brazil where they have developed animal husbandry (cow and, subsequently, goat and sheep). Intense farming activities resulted in the degradation of primitive forest and succeeding damage to triatomine silvatic biotopes. Simultaneously, many artificial structures built by the farmers have provided new habitats for triatomines. However, the combined influence of population type, residence pattern and practices of husbandry, remains little known on the triatomine infestation. The aim of this study was to pro- 
vide an analysis of these factors among a farming population of northeastern Brazil. The family groups were firstly classified into different categories, according to the activity (agriculture or husbandry) and the way to exercise it. The peridomicile organization and its possible infestation by triatomine bugs were then documented for each category.

\section{MATERIALS AND METHODS}

\section{STUDY AREA}

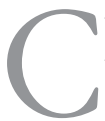
uraça is a rural district of $6,406 \mathrm{~km}^{2}$ situated in the Bahia State, Brazil ( $8^{\circ} 59^{\prime}$ S; $39^{\circ} 54^{\prime}$ W). The area has expanded progressively because of livestock farming and the small city of Curaçá was founded in 1832 as harbor on the São Francisco River. Out of almost 29,000 inhabitants, 18,000 are living in the rural area where they practice mainly the farming. The irrigation was introduced in the land located along the São Francisco River several decades ago. More than $60 \%$ of the population is currently living along the river where fruit and vegetable are produced. The rest of the population lives in isolated farms in the middle of a globally degraded caatinga with, however, large patches of more preserved vegetation. It mainly rears goat, sheep, and a few cattle. This rural district, that exhibits high rates of poverty, inequality and social exclusion combined with low rates of education and employment, is one of the more deprived of Brazil (Pochmann, 2003).

\section{SURVEY DESIGN}

From September to November 2002, a survey of 136 farms randomly selected was carried out in the Curaça district. One third of the sample population was farmers living in the agricultural zone near the São Francisco River, and the rest lived inland of livestock. The last group was homogeneously distributed into two main zones of vegetation, both pertaining to the caatinga: $i$ ) region near Curaça characterized by damaged vegetation due to intense livestock rearing; $i$ ) preserved shrub land. All visited domiciliary units (including domicile and peridomicile with annexes) were carefully mapped and described. Houses were built from stick covered with mud (taipa), raw mud bricks (adobe), artisanal or industrial bricks and cement. The roofs were always made of local or industrial tiles. The peridomicile was defined as the full area located around the house and supporting useful annexes for men and animals. A standard questionnaire concerned with the family origin and composition, ownership of house, type and number of animals, daily farmer's activities and main income sources, was filled out according to the responses of each householder. Informal interviews were directed toward the history of the district and farmer biography.

\section{INSECT CAPTURE}

Various potential habitats were searched for the presence of triatomines in the domicile and peridomicile. Each dwelling was investigated for approximately one hour by a trained technician of the Chagas Disease Control program. The collected bugs where conserved in a labeled plastic box with filter paper, using one box for each capture site, and sent to laboratory for further analysis. We considered that a domiciliary unit was infested if, at least, one living bug was captured inside the house or peridomicile.

\section{DATA ANALYSES}

The population surveyed was classified into different categories, depending on the main activity (agriculture, animal rearing, casual work and unemployed), existence of a retirement pension, and main source of income (sale of animals or agricultural products, retirement pension, occasional work, employee by a breeder). Of the 136 visited dwellings, four were excluded because householders were not agro-pastoralists but employees of public service. The following data were computed as nominal variables of two or three classes: family composition (single/couple/family); age of domicile $(<20$ years $>20$ years $)$; surface of domiciliary unit $\left(<2,000 \mathrm{~m}^{2} />2,000 \mathrm{~m}^{2}\right)$; surface of house (small $<40 \mathrm{~m}^{2} /$ middle size between 40 and $60 \mathrm{~m}^{2}$ / large $\geq 60 \mathrm{~m}^{2}$ ); building material (taipa/adobe/brick or commercial material); presence of piles of material inside the peridomicile (yes/no); number of pens $(<3 /$ $\geq 3$ ); surface of pens (small $<150 \mathrm{~m}^{2} /$ middle size 150 $550 \mathrm{~m}^{2} /$ large $\left.\geq 550 \mathrm{~m}^{2}\right)$; length of pen fences $(<80 \mathrm{~m} /$ $\geq 80 \mathrm{~m}$ ); roofed pen (yes/no); number of goats or sheep (none/few $<100 /$ many $\geq 100$ ); number of cows (none/few $<15 /$ many $\geq 15$ ); number of dogs $(<3$ / $\geq 3$ ). The association between: $i$ ) the population category and variables concerning the domiciliary unit, and ii) population category and dwelling infestation, were tested by chi $^{2}$ or exact Fisher test. Data about daily life of farmers were issued from interviews.

\section{RESULTS}

\section{BEHAVIORAL PATTERN OF THE POPULATION}

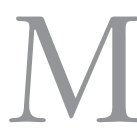
ost of the farmers living near the São Francisco River were coming from inland farms or, sometimes, other Brazilian States, particularly Ceara, attracted by irrigation projects of the area. The population, for the most part, was constituted of families with young children and earned a living with 
market gardening they practiced in irrigated fields. They had built houses close by each other and the labor in irrigated fields was their main activity. They only ventured into the caatinga for occasional hunting trips, plant collecting or firewood. The farms generally included a piece of land, further inland, where few livestock might be reared. Some farmers owned their farm while the others were regularly employed in neighboring farms. Casual workers were homogeneously distributed in the caatinga area and most of them were born in the district. They were generally young, single or just married, with no or few children. They lived in various types of dwelling that they owned, borrowed from family or occupied as temporary workers. They mainly worked toward maintaining the farm, sometimes in irrigated fields or collecting fruits in season. They walked across the caatinga for cattle rearing, hunting or collecting wild fruits, plants and wood. Exclusive and retired cattle farmers had similar activities but a slightly different way of life. Because cattle work was a full time activity, exclusive young farmers spent most of the day on horseback in the caatinga herding and watching on the animals. At noon, they often took a nap, sleeping in the shade of rock or tree. At night, they kept generally all the horse equipment inside dwelling. Unlike young cattle farmers, old people had less contact with caatinga. Old cattle farmers usually carried on rearing some animals but it was above all the retirement pension that gave them a regular income. They spent time in the farm for receiving their relatives and performing maintenance works.

Finally, four groups of people might be constituted: 1. Farmers: they practiced irrigated agriculture and lived near the São Francisco river; they were retired or not; they supported by market gardening or casual agricultural work;

2. Casual workers: they lived in the caatinga of casual work mainly related to cattle farming. They did not have any regular income except, sometimes received a retirement pension always supplemented by casual work;

3. Exclusive cattle farmers: they practiced intense animal farming and lived in the caatinga (with two exceptions); they were not retired and drew incomes from livestock sale or regular work for a wealthy landlord;

4. Retired cattle farmers: they were officially retired and lived in the caatinga but still practiced animal farming; they had retirement allocation completed with occasional sale of animals.

\section{PERIDOMICILE STRUCTURING AND POPULATION GROUP}

The investigated peridomiciles had an average of $8.3 \pm$ 4.4 annexes. They were mainly made up of pens (3.1 \pm
2.0) surrounded and divided by wood fences, brick or tile piles $(2.7 \pm 1.7)$, trees used as chicken coops, fowl houses and animal shelters. Generally, the organization of peridomestic structures was different between farmers and casual workers on the one hand, and cattle farmers (groups 3 and 4) on the other hand (Table I). In farmers and casual workers, the dwelling was more newly built, the pens smaller and the sheep and goat flock less important. In comparison with the three other groups, the farmers had smaller domestic units with a reduced peridomestic area and smaller cattle pen. The farmers were less involved in animal rearing than others groups and just rear few goats or sheep for their own needs. There was no difference between the groups in regard to building material of dwellings, the existence of brick and tile piles, the number of dogs and the immediate environment (preserved or damaged caatinga).

\section{TRIATOMINE INFESTATION}

In total, 359 triatomines were collected in 66 of the 131 domestic units investigated (50.4\%). T. brasiliensis was the dominant species in number of collected individuals (286 vs 73 T. pseudomaculata specimens). T. brasiliensis was collected alone in 41 domestic units, T. pseudomaculata alone in 18 , and both species together in seven. The infestation rate according to the group of people is given in Table II. T. pseudomaculata infestation was positively associated with retired cattle farmers ( $\mathrm{p}$-value $=0.003$ ) and negatively associated with farmers ( $\mathrm{p}$-value $=0.015$ ). On the other hand, T. brasiliensis infestation was associated with none of the population categories ( $\mathrm{p}$-value $=0.098$ ) When the population was pooled according to the peridomestic characteristics and livestock, both groups with larger structures and livestock (exclusive and retired cattle farmers) also presented the higher T. pseudomaculata infestation rate $(26.8 \%$ vs $8.9 \%$; p-value $=$ 0.013). On the other hand, the size of structures and livestock had not influence on the T. brasiliensis infestation rate $(37.3$ vs $35.7 \%$; -value $=0.86)$. When the population was pooled according to the way of life (contact with the caatinga and mobility), both groups with more sedentary behavior (farmers and retired cattle farmers) had the lowest $T$. brasiliensis infestation rate $(27.1 \%$ vs $47.5 \%$; p-value $=0.019)$. The lifestyle had not influence on the T. pseudomaculata infestation rate $(21.4$ vs $16.4 \%$; p-value $=0.51)$.

\section{DISCUSSION}

The study area belongs to the northeast semi-arid zone of Brazil where T. brasiliensis and T. pseudomaculata are autochthonous triatomines des- 


\begin{tabular}{|c|c|c|c|c|c|}
\hline Features of domestic unit & Category & No. & $\begin{array}{c}\text { Farmers (30) } \\
\text { No. }(\%)\end{array}$ & & $\begin{array}{c}\text { Retired farmers }(40) \\
\text { No. }(\%)\end{array}$ \\
\hline Surface of the domestic unit & $\begin{array}{l}<2,000 \mathrm{~m}^{2} \\
\geq 2,000 \mathrm{~m}^{2} \\
\text { p-value }\end{array}$ & $\begin{array}{l}57 \\
74\end{array}$ & $\begin{array}{r}24(80) \\
6(20)\end{array}$ & $<0.0001$ & $\begin{array}{l}33(32.6) \\
68(67.3)\end{array}$ \\
\hline House surface & $\begin{array}{l}<40 \mathrm{~m}^{2} \\
40-80 \mathrm{~m}^{2} \\
\geq 80 \mathrm{~m}^{2} \\
\text { p-value }\end{array}$ & $\begin{array}{l}36 \\
43 \\
52\end{array}$ & 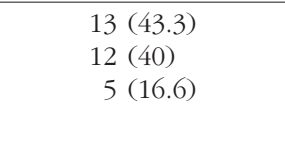 & 0.0092 & $\begin{array}{ll}23 & (22.7) \\
31 & (30.7) \\
47 & (46.5)\end{array}$ \\
\hline \multirow[t]{2}{*}{ No. of cows } & $\begin{array}{l}<15 \\
\geq 15 \\
\text { p-value }\end{array}$ & $\begin{array}{l}91 \\
40\end{array}$ & $\begin{array}{l}30(100) \\
0\end{array}$ & $<0.0001$ & $\begin{array}{l}61(60.3) \\
40(39.6)\end{array}$ \\
\hline & & & $\begin{array}{c}\text { Farmers (30) } \\
\text { Casual workers (26) }\end{array}$ & & $\begin{array}{l}\text { Exclusive farmers }(35) \\
\text { Retired farmers }(40)\end{array}$ \\
\hline Age of house & $\begin{array}{l}<20 \text { years } \\
>20 \text { years } \\
\text { p-value }\end{array}$ & $\begin{array}{l}45 \\
72\end{array}$ & $\begin{array}{l}26(49.4) \\
22(39.2)\end{array}$ & 0.0042 & $\begin{array}{l}19(25.3) \\
50(66.7)\end{array}$ \\
\hline Number of pens & $\begin{array}{l}<3 \\
>3 \\
\text { p-value }\end{array}$ & $\begin{array}{l}56 \\
75\end{array}$ & $\begin{array}{l}36(64.3) \\
20(35.7)\end{array}$ & $<0.0001$ & $\begin{array}{l}20(26.7) \\
55(73.3)\end{array}$ \\
\hline Surface of pens & $\begin{array}{l}<150 \mathrm{~m}^{2} \\
150-550 \mathrm{~m}^{2} \\
\geq 550 \mathrm{~m}^{2} \\
\text { p-value }\end{array}$ & $\begin{array}{l}42 \\
50 \\
25\end{array}$ & $\begin{array}{r}24(55.8) \\
11(25.6) \\
8(18.6)\end{array}$ & 0.002 & $\begin{array}{ll}18 & (24.3) \\
39 & (52.7) \\
17 & (22.9)\end{array}$ \\
\hline Length of pen fences & $\begin{array}{l}<80 \mathrm{~m} \\
\geq 80 \mathrm{~m} \\
\text { p-value }\end{array}$ & $\begin{array}{l}54 \\
62\end{array}$ & $\begin{array}{l}30(55.6) \\
12(44.4)\end{array}$ & $<0.0001$ & $\begin{array}{l}24(19.6) \\
50(80.6)\end{array}$ \\
\hline Roofed pens & $\begin{array}{l}\text { No } \\
\text { Yes } \\
\text { p-value }\end{array}$ & $\begin{array}{l}96 \\
35\end{array}$ & $\begin{array}{r}47(83.9) \\
9(16.1)\end{array}$ & 0.0273 & $\begin{array}{l}49(65.3) \\
26(34.6)\end{array}$ \\
\hline No. of goats and sheep & $\begin{array}{l}<100 \\
\geq 100 \\
\text { p-value }\end{array}$ & $\begin{array}{l}56 \\
66\end{array}$ & $\begin{array}{l}36(75) \\
12(25)\end{array}$ & $<0.0001$ & $\begin{array}{l}20(27.1) \\
54(72.9)\end{array}$ \\
\hline
\end{tabular}

Table I. - Characteristics of domiciliary unit in the four agropastoral groups issued from the population surveyed.

\begin{tabular}{|c|c|c|c|}
\hline \multirow[b]{2}{*}{ Classification by } & \multirow[b]{2}{*}{$\mathbf{N}$} & \multicolumn{2}{|c|}{ Dwelling infestation with } \\
\hline & & $\begin{array}{c}\text { T. brasiliensis } \\
\mathrm{N}(\%)\end{array}$ & $\begin{array}{c}\text { T. pseudomaculata } \\
\text { N (\%) }\end{array}$ \\
\hline \multicolumn{4}{|l|}{ Population categories } \\
\hline Farmers & 30 & $7(23.33)$ & $1(3.33)$ \\
\hline Casual workers & 26 & $13(50)$ & $4(15.38)$ \\
\hline Exclusive breeders & 35 & $16(47.5)$ & $6(17.14)$ \\
\hline Retired breeders & 40 & $12(30)$ & $14(35)$ \\
\hline p-value & & 0.0984 & 0.0085 \\
\hline \multicolumn{4}{|l|}{ Peridomicile organisation } \\
\hline $\begin{array}{l}\text { Farmers \& casual workers } \\
\text { "(Small dwelling; few animals \& corrals)" }\end{array}$ & 56 & $20(35.7)$ & $5(8.9)$ \\
\hline $\begin{array}{l}\text { Breeders exclusive \& retired } \\
\text { "(Large dwelling; many animals \& corrals)" }\end{array}$ & 75 & $28(37.3)$ & $20(26.8)$ \\
\hline p-value & & 0.8571 & 0.013 \\
\hline \multicolumn{4}{|l|}{ Way of life } \\
\hline $\begin{array}{l}\text { Farmers \& retired breeders } \\
\text { "(Less contact with caatinga; more settled)" }\end{array}$ & 70 & $19(27.14)$ & $15(21.43)$ \\
\hline $\begin{array}{l}\text { Casual workers \& exclusive breeders } \\
\text { "(More contact with caatinga; more mobile)" }\end{array}$ & 61 & $29(47.54)$ & $10(16.39)$ \\
\hline p-value & & 0.0187 & 0.5103 \\
\hline
\end{tabular}

Table II. - Distribution of Triatoma species according to the population surveyed. 
cribed for a long time. By the fact that $T$. brasiliensis has adapted to the human environment and particularly to house in some regions, this species is considered as epidemiologically linked to human Chagas disease. On the other hand, large colonies of T. pseudomaculata are only formed in the peridomestic environment and, because this species is poorly adapted to the house, it is considered of secondary importance (WHO, 2002). Since the $16^{\text {th }}$ century, the increasing rural populating and subsequent anthropic pressure by livestock farming have damaged the caatinga. In recent decades, irrigation projects along the São Francisco River have also attracted populations from Pernambuco and Ceara and promoted human settlement. The unfavorable environmental changes have resulted in the disturbance on triatomine silvatic ecology and led triatomines to move to peridomestic/domestic structures where they could find a variety of hiding places and food for forming colonies and growing (Schofield, 1994). The features of natural and artificial structures that provide refuge to Triatominae in the human environment were widely studied with the aim to quantify the risk factors for epidemiological diagnosis and optimize the control program activities (Cecere et al., 1997; Salvatella et al., 1998). On the other hand, the knowledge on the initial stage of triatomine invasion of the human environment is based on rough data. If the flight to light source of silvatic triatomines is considered as an important means of dispersal and invasion in Triatominae (Zeledon \& Rabinovich, 1981; Schofield et al., 1992, Vazquez-Prokopec et al.,2004) the role of human activities on the passive transport of insects from the silvatic environment to house is little-known (Coimbra, 1988; Walter, 2003). In our area, the infestation rate of domiciliary units is twice higher with $T$. brasiliensis than with $T$. pseudomaculata. However, this apparent higher prevalence may be overestimated: whatever its stage, $T$. brasiliensis is a fast and colored insect and, also because of its colonies generally large, it is more easily detectable. Walter et al. (2004) suggest that infestation of domiciliary units with $T$. pseudomaculata is associated with the proximity of shrub plots. In areas where the caatinga has been heavily cleared through livestock or irrigation farming, the dwelling infestation with T. pseudomaculata significantly decreases. So, the farmers living in clearly areas near the river and practicing irrigated agriculture are less exposed than other groups to triatomine infestation. Among the three other groups that are homogeneously distributed throughout the caatinga, retired farmers are the most exposed to T. pseudomaculata infestation for a reason probably independent of environmental conditions. On the other hand, the four groups seem to be similarly exposed to the infestation with $T$. brasiliensis.

Considering the scale level of the domiciliary unit, previous studies have shown that $T$. brasiliensis and T.pseu- domaculata occupy and share the same type of peridomestic ecotopes: brick and tiles pile, pen fence, chicken coop and other animal shelter (Costa et al., 1998; Oliveira-Lima et al., 2000; Diotaiuti et al., 2000). Walter et al. (2004) have shown that the number and size of pens are risk factors for peridomestic infestation with both triatomine species, while the number of goats, cows and dogs significantly increases the risk of T. pseudomaculata infestation. The current study shows that the dwellings of farmers and casual workers are smaller, with few animals and are consequently less infested with T. pseudomaculata $(\mathrm{p}<0.05)$. On the other hand, the T. brasiliensis infestation rate is not linked to any group of population and does not vary significantly according to the peridomestic and livestock size.

At level of triatomine microhabitats, some authors have noted that T. pseudomaculata and T. brasiliensis divide the same artificial ecotopes (Bento et al., 1989; Sarquis et al., 2004). At Curaça, we have observed that both species may share the same post fence or chicken coop (Carbajal de la Fuente et al., unpublished data). The interspecific competition would always be favorable to T. brasiliensis, in regard of its shorter life cycle (Pinto Soares et al., 2000). Consequently, T. pseudomaculata would infest the peridomestic structures located near shrub plots, which accumulate cattle and corrals and are not invaded by $T$. brasiliensis.

The mobility of population and its close contact with caatinga (casual workers and exclusive cattle farmers pooled) seem to favor the $T$. brasiliensis infestation of dwellings. These results rather support the hypothesis of $T$. brasiliensis passive transport by man or animal from its source (rocks) towards the dwellings. It is also possible that $T$. brasiliensis (or a semi-domesticated sub-population of $T$. brasiliensis as noticed by Costa et al., 2002) is passively dispersed by men from one house to another. Field experiments of light trapping, showing that $T$. brasiliensis is not considered a good flyer compared with T. pseudomaculata (Carbajal de la Fuente et al., in press), support this hypothesis. In this context, the passive introduction of triatomines by the most mobile groups would strongly favour the installation of the more competitive T. brasiliensis inside the peridomicile.

By the environmental changes which result of its agropastoral activities, the man is responsible for the disturbance of the triatomine silvatic ecology. By its behavior, the man may also facilitate the triatomine intrusion into the household. So, this study gives indication of its direct involvement in the dispersal of insects through its moving throughout the caatinga, and in the first stage of dwelling invasion. Then the characteristics of the dwelling and organization of annexes (location, substrate, sort, presence of animals) will allow or not the colonization by the vector. Finally, the inter-spe- 
cific competition will favor one species over the other. Control measures against triatomine infestation have not to focus only on peridomiciliar organization but have also to take into account the bio-ecology of local species and human activities that favor the intrusion of vectors inside the peridomestic areas. Insecticide spraying and house improvement were effective for the elimination of the exogenous T. infestans. On the other hand, a better understanding of human behaviors that favor the triatomine peridomestic infestation is required to provide advice for human communities in order to reduce the incursion of silvatic vectors. A better understanding of the peridomestic ecology of vectors and interspecific competition for colonizing ecotopes is also required.

\section{ACKNOWLEDGEMENTS}

The study received financial support from the CNPq, FIOCRUZ and IRD, and benefited from the collaboration of the CDS and FUNASA. E. Salustianu de Brito, G. Sales de Serra, J.I. de Santana and F. Nelson Filho gave invaluable assistance in the field work, as well as G. dos Santos Mendonça. The authors thank also the population of Curaça. The study is part of the project EDCTA (Écologie du paysage, dynamique des agroécosystèmes et complexes éco-pathogènes : la définition du risque écoépidémiologique dans le cas de la trypanosomose américaine) coordinated by Laure Emperaire (IRD) and Ana-Maria Jansen (FIOCRUZ).

\section{REFERENCES}

Bento O.N., Freitas M.R. \& Pinto A. Epidemiologia da doença de Chagas nos municipios de Castelo do Piaui e Pedro II, estado do Piaui, Brasil. Revista de la Sociedad Brasileira de Malaria y Doença Tropicales, 1989, 22 (2), 73-79.

Cecere M.C., Gürtler R.E., Canale D., Chutt R. \& Cohen J.E. The role of the peridomiciliary area in the elimination of Triatoma infestans from rural Argentine communities. Pan American Journal of Public Health, 1997, 1, 273-279.

CoImbra C.J. Human settlements, demographic pattern and epidemiology in Lowland Amazonia: the case of Chagas disease. American Anthropology, 1988, 90, 82-97.

Correa R. \& Espinola H. Descriçao de Triatoma pseudomaculata, nova especie de triatomineo de Sobral Ceara. Arqivos de Higiene y Saúde Pública, 1964, 29, 115-127.

Costa J., Almeida C.E., Dotson E.M., Lins A., Costa Vinhaes M., Silveira A.C. \& Ben Beard C. The epidemiologic importance of Triatoma brasiliensis as a Chagas Disease vector in Brazil: a revision of domiciliary captures during 19931999. Memórias do Instituto Oswaldo Cruz, 2003, 98 (4), 443-449.

Costa J., Peterson A.T. \& Ben Beard C.B. Ecologic niche modelling and differentiation of populations of Triatoma brasiliensis Neiva, 1911, the most important Chagas'disease vector in northeastern Brazil (hemiptera, reduviidae, triatominae). American Journal of Tropical Medicine and Hygiene, 2002, 67 (5), 516-520.

Costa J., Ribeiro de Almeida J., Britto C., Duarte R., MarCHON-Silva V. \& DE PACHeco S. Ecotopes, natural infection and trophic resources of Triatoma brasiliensis (Hemiptera, Reduviidae, Triatominae). Memórias do Instituto Oswaldo Cruz, 1998, 93 (1), 7-13.

Dias J.C.P., Machado E.M., Fernandes A.N. \& Costa Vinhaes M. General situation and perspectives of Chagas disease in northeastern region, Brazil. Cadernos de Saude Publica, 2000, 16 (2), 13-34.

Diotaiuti L., Faria Filho O.F., Carneiro F.C.F. Dias J.C.P., Pires H.H.R. \& SCHOFIELD C.J. Operational aspects of Triatoma brasiliensis control. Cadernos de Saude Publica, 2000, 16 (2), 61-67.

Lehane M.J. \& SCHOfIELD C.J. Flight initiation in Triatoma infestans (Klug) (Hemiptera: Reduviidae). Bulletin of Entomological Research. 1982, 72, 497-510.

Neiva A. \& Penna B. Viagem cientifica pelo Norte da Bahia, sudeste de pernambuco, Sul do Piaui e do Norte a Sul de Goias. Memórias do Instituto Oswaldo Cruz, 1916, 8 (3), 74-224.

Oliveira-Lima J.W., Faria Filho O.F., Furtado Vieira J.B., Gadelha F.V. \& Oliveira Filho A.M. Peridomiciliary changes and implications for Triatoma brasiliensis control. Cadernos de Saude Publica, 2000, 16 (suppl. 2), 75-81.

Pinto Soares R.P., Evangelista L.G., Soares Laranja L. \& DioTAIUTI L. Population dynamics and feeding behavior of Triatoma brasiliensis and Triatoma pseudomaculata, main vectors of Chagas disease in northeastern Brazil. Memórias do Instituto Oswaldo Cruz, 2000, 95 (2), 151-155.

Pochmann M. \& Amorim R. (organizadores). Atlas da Exclusão social no Brasil. 2003, São Paulo, Editora Cortez.

Salvatella R., Franca Rodriguez M.E., Curto de Casas S.I., Barata J.M.S. \& CARCAVAllo R.U. Habitats and related fauna: B - Human environment: dwellings ans peridomiciliary sites. In: Atlas of Chagas disease vectors in the Americas, Vol. II, Carcavallo R.U., Galindez Girón I., Jurberg J. \& Lent H. (org.), Rio de Janeiro, Fiocruz, 1998, 601-619.

Sarquis O., Borges-Pereira J., Mac Cord J.R., Gomes T.F., CABEllo P.H. \& Lima M.M. Epidemiology of Chagas disease in Jaguaruana, Ceará, Brazil. I. Presence of triatomines and index of trypanosoma cruzi infection in four localities of a rural area. Memórias do Instituto Oswaldo Cruz, 2004, 99 (3), 263-270.

Schofield C.J., Lehane M.J., McEwen P.K., Catala S. \& Gorla D.E. Dispersive flight by Triatoma infestans under natural climatic conditions in Argentina. Medical and Veterinary Entomology, 1992, 26, 51-56.

SCHOFIELD C.J. Triatominae: biology and control. Eurocommunica Publications Ed., West Sussex, UK, 1994, 80 p.

Silveira A.C. \& Vinhaes M.C. Doença de Chagas: aspectos epidemiologicos e de controle. Revista da Sociedade Brasileira de Medicina Tropical, 1998, 31, 15-60.

Silveira A.C., Costa Vinhaes M., Lira E. \& Araujo E. O controle de Triatoma brasiliensis e Triatoma pseudomaculata. 
II. Avaliaçao do controle fisico, pela melhoria habitacional, e caracterizaçao do ambiente peridomiciliar mais e menos favoravel à persistencia da infestaçao ou reinfestaçao por Triatoma brasiliensis e Triatoma pseudomaculata. 1998, Brasilia, OPAS, 62 p.

Vazquez-Prokopec G.M., Ceballos L.A., Kitron U. \& Gutler R.E. Active dispersal of natural populations of Triatoma infestans (Hemiptera: Reduviidae) in rural northwestern Argentina. Journal of Medical Entomology, 2004, 41 (6), 614-621.

WALter A.E. Human activities and American trypanosomiasis. Review of the literature. Parasite, 2003, 10 (3), 191-204.

Walter A.E., Pojo do Rego I., Fereira A.J. \& Rogier C. Risk factors for reinvasion of human dwellings by sylvatic triatomines in northern Bahia State, Brazil. Cadernos de Saúde Pública, 2005, 21 (3), 974-978.

WHO. Control of Chagas disease. Technical Report Series no. 905, Geneva, 2002, 109.

ZELEDON R. \& RABINOVICH J.E. Chagas'disease: an ecological appraisal with special emphasis on its insect vectors. Annual Review of Entomology, 1981, 26, 101-133.

Reçu le 2 janvier 2006

Accepté le 9 mai 2006 